\title{
Regulation of Brain Proteolytic Activity Is Necessary for the In Vivo Function of NMDA Receptors
}

\author{
Mirna Kvajo, ${ }^{1}$ Hugo Albrecht, ${ }^{1,5}$ Marita Meins, ${ }^{1}$ Ulrich Hengst, ${ }^{1,2}$ Edgardo Troncoso, ${ }^{3}$ Sandrine Lefort, ${ }^{4}$ Jozsef Z. Kiss, ${ }^{3}$ \\ Carl C. H. Petersen, ${ }^{4}$ and Denis Monard ${ }^{1}$ \\ ${ }^{1}$ Friedrich Miescher Institute, CH-4058 Basel, Switzerland, 2Department of Pharmacology, Weill Medical College of Cornell University, New York, New York \\ 10021, ${ }^{3}$ Department of Morphology, University of Geneva Medical School, CH-1211 Geneva, Switzerland, ${ }^{4}$ Laboratory of Sensory Processing, Brain and \\ Mind Institute, Ecole Polytechnique Federale de Lausanne, CH-1015 Lausanne, Switzerland, and 5Discovery Partners International AG, CH-4123 Allschwil, \\ Switzerland
}

Serine proteases are considered to be involved in plasticity-related events in the nervous system, but their in vivo targets and the importance of their control by endogenous inhibitors are still not clarified. Here, we demonstrate the crucial role of a potent serine protease inhibitor, protease nexin-1 (PN-1), in the regulation of activity-dependent brain proteolytic activity and the functioning of sensory pathways. Neuronal activity regulates the expression of $\mathrm{PN}-1$, which in turn controls brain proteolytic activity. In PN-1 ${ }^{-1-}$ mice, absence of PN-1 leads to increased brain proteolytic activity, which is correlated with an activity-dependent decrease in the NR1 subunit of the NMDA receptor. Correspondingly, reduced NMDA receptor signaling is detected in their barrel cortex. This is coupled to decreased sensory evoked potentials in the barrel cortex and impaired whisker-dependent sensory motor function. Thus, a tight control of serine protease activity is critical for the in vivo function of the NMDA receptors and the proper function of sensory pathways.

Key words: barrel cortex; NMDA receptors; plasticity; protease nexin-1; serine proteases; serine protease inhibitors

\section{Introduction}

Neuronal activity can induce modifications in neuronal circuits and synapse morphology, sustaining brain plasticity (Buonomano and Merzenich, 1998). Regulation of gene expression by synaptic events is one of the mechanisms translating short-lasting sensory experience into such structural modifications. Therefore, it is important to identify activity-regulated genes and their products involved in synaptic remodeling.

Extracellular proteolysis provides an attractive mechanism controlling structural changes in neuronal plasticity. Tissue plasminogen activator (tPA) is one of the serine proteases involved in such processes. Its expression is regulated by neuronal activity, including long-term potentiation (LTP) in the hippocampus (Qian et al., 1993), complex motor learning tasks in the cerebellum (Seeds et al., 1995), and stress in the amygdala (Pawlak et al., 2003). Hippocampal LTP and cerebellar motor learning are modified in mice overexpressing or lacking tPA (Madani et al., 1999; Calabresi et al., 2000; Seeds et al., 2003). In vitro, depolarization stimulates tPA release (Gualandris et al., 1996), and its levels are regulated by internalization through the low density lipoprotein receptor-like protein (LRP) (Bu et al., 1992), a multifunctional receptor with diverse biological roles (Herz and

\footnotetext{
Received June 21, 2004; revised Sept. 13, 2004; accepted Sept. 13, 2004.

This work was supported by the Novartis Research Foundation, Swiss National Science Foundation Grant 3100A0103832, and the Leenaards Foundation. We thank Elisabeth Fries, Sabrina Taieb, and Jean-François Spetz for valuable technical assistance and Andrew Matus, Andreas Lüthi, and Patrick King for advice and critical reading of this manuscript.

Correspondence should be addressed to Denis Monard at the above address. E-mail: denis.monard@fmi.ch. DOI:10.1523/JNEUROSCI.3306-04.2004

Copyright $\odot 2004$ Society for Neuroscience $\quad 0270-6474 / 04 / 249734-10 \$ 15.00 / 0$
}

Strickland, 2001). In hippocampal slices, LRP appears to be important for LTP generation (Zhuo et al., 2000).

Although the functions of serine proteases in activitydependent processes have been well characterized, few studies have examined the importance of proteolytic homeostasis for brain function, especially the role of protease inhibitors. Among those, protease nexin-1 (PN-1), a potent secreted serine protease inhibitor of the serpin superfamily (Gloor et al., 1986; Farrell et al., 1988), is strongly expressed in the mature CNS and prominent in cortical cell populations (Mansuy et al., 1993). Studies in hippocampal slices from PN-1-deficient mice showed decreased LTP and decreased NMDA receptor (NMDAR)-mediated synaptic currents (Luthi et al., 1997), whereas PN-1 overexpressing mice had enhanced LTP (Luthi et al., 1997) and a progressive neuronal and motor dysfunction (Meins et al., 2001).

In this work, we investigated the importance of PN-1mediated control of brain proteolytic activity in activitydependent events and for the in vivo function of sensory pathways. First, to determine whether neuronal activity affects PN-1 expression, we created reporter mice with a $\beta$-galactosidase marker gene inserted in the PN-1 locus and used the whisker-tobarrel cortex pathway, which provides advantages for topological, histological, and electrophysiological studies (Woolsey and Van der Loos, 1970; Barth et al., 2000; Fox, 2002; Knott et al., 2002). Second, using PN-1-deficient mice, we investigated the effects of altered brain proteolytic activity on NMDA receptors, glutamate-gated ion channels that are key regulators in neuronal plasticity (Dingledine et al., 1999). Finally, we performed behavioral studies to assess the physiological consequences of these modifications. 
Here, we report that brain proteolytic activity was strongly regulated by neuronal activity, with $\mathrm{PN}-1$ being a major controlling element. In $\mathrm{PN}-1^{-/-}$mice, increased proteolytic activity was associated with reduced NMDA receptor levels and function, decreased sensory-evoked potentials (SEPs) in the barrel cortex, and impaired whisker-dependant performance in behavioral tests, suggesting that a tight control of proteolysis is critical for NMDA receptor function and performance of sensory pathways.

\section{Materials and Methods}

Experimental animals. To create a PN-1 HAPN-1-lacZ/HAPN-1-lacZ $(\mathrm{PN}-1 \mathrm{KI})$ mouse, we replaced exon II of the $P N-1$ gene with a construct containing the PN-1 secretion signal sequence ( $56 \mathrm{bp}$ ) in front of a hemagglutinin (HA)-tagged mature PN-1 cDNA (1137 bp). This sequence was coupled by an internal ribosome entry site (IRES) sequence to the nucleolar localization site (NLS)-LacZ-pA and the thymidine kinase-Neo-pA cassette. The IRES allowed the independent translation of PN-1 and $\beta$-galactosidase from the transcript, whereas the NLS targeted $\beta$-galactosidase to the cell nuclei (see Fig. $1 A$ ). The targeting construct was inserted by homologous recombination into 129SV embryonic stem cells. The targeted clones were produced by morula aggregation, producing germline chimeras. Animals heterozygous for the targeted $P N-1$ allele were established with a mixed genetic background. Four PCR primers were used to screen for construct insertion. Primer HA23 annealed within the genomic DNA, whereas HA26 annealed within the HA-tag sequence, leading to a PCR product only in mice carrying the insertion. HA15 annealed within genomic DNA, whereas HA25 annealed within the sequence of PN-1 in the wild-type and that present in the insert. A difference in band size resulting from the HA-tag present in the inserted PN-1 sequence allowed distinction between homozygote and heterozygote mice (see Fig. $1 B$ ).

PN-1 $1^{-/-}$mice (Luthi et al., 1997) were backcrossed for 12 generations in the C57BL/6 line. Heterozygous mating generated $\mathrm{PN}-1^{-1-}$ and $\mathrm{PN}-$ $1^{+/+}$littermates. Genotyping was performed on DNA from tail biopsies by PCR. C57BL/6 mice were purchased from Charles River (Arbresle, France). All experimental animals were 4-8 months of age. All animal experiments were approved by the Swiss Veterinary Authorities.

Sensory deprivation. The "single-spared whisker" deprivation pattern was imposed as described previously (Barth et al., 2000) with the difference that the whiskers were trimmed and not pulled out. The "unilateral" deprivation pattern was done in the same way, except that all whiskers on one side were removed.

Enriched environment. During exposure to enriched environment (EE), mice were individually housed in a large cage equipped with objects of different shape and texture such as tunnels, grids, plastic objects, aluminum foil, and paper. When the enrichment was longer than $24 \mathrm{hr}$, objects were replaced or displaced on a daily basis. Control mice were single-housed in standard small cages. Before the experiment, all mice were single-housed in standard small cages for at least 3 weeks.

$\beta$-Galactosidase histochemistry on sections and whole-mount staining of brains. Mice were anesthetized and transcardially perfused with ice-cold PBS and 4\% paraformaldehyde (PFA). Brains were dissected out, postfixed for $2 \mathrm{hr}$, equilibrated overnight in 30\% sucrose, and quickly frozen in Tissue-Tek OCT (Sakura Finetek, Tokyo, Japan). Coronal cryostat (50 $\mu \mathrm{m}$ thick) and vibratome (400 $\mu \mathrm{m}$ thick) sagittal sections were briefly air-dried, fixed for $20 \mathrm{~min}$ in 4\% PFA, washed three times for $15 \mathrm{~min}$ in solution B ( $2 \mathrm{~mm} \mathrm{MgCl}_{2}, 0.02 \%$ Nonidet P-40, 0.01\% sodium deoxycholate in PBS), and incubated for $6 \mathrm{hr}$ or overnight at $37^{\circ} \mathrm{C}$ in solution C [solution B plus $5 \mathrm{~mm}$ potassium ferricyanide, $5 \mathrm{~mm}$ potassium ferrocyanide, and $0.5 \mathrm{mg} / \mathrm{ml}$ 5-bromo-4-chloro-3-indolyl-b-D-galactopyranoside (X-gal)] (Roche, Basel, Switzerland). The whole-mount staining of brains was done essentially as described previously (Barth et al., 2000).

Proteolytic assays. Mice were perfused with ice-cold PBS, and brains were rapidly dissected out and homogenized in a homogenizing buffer (20 mm sodium phosphate buffer, $320 \mathrm{~mm}$ sucrose, $1 \mathrm{~mm}$ EDTA, 0.2\% Tween 20). For each experiment, a separate set of mice was used. Dilutions of cleared homogenates $(100 \mu \mathrm{g}$ of protein in $80 \mu \mathrm{l})$ were mixed in a 96-well microtiter plate with $10 \mu \mathrm{l}$ of S-2288 (H-D-Ile-Pro-Arg-pNA) substrate and immediately measured. The amidolytic activity was determined as described previously (Hengst et al., 2001). Statistical analysis was performed using the Prism 4 (GraphPad, San Diego, CA) statistical package.

In situ zymography. Zymography to detect tPA was performed essentially as described previously (Sappino et al., 1993). Mice were perfused with ice-cold PBS, and the brains were rapidly dissected out and quick frozen. Cryostat sections $(12 \mu \mathrm{m})$ were overlaid with a mixture containing $1 \%$ agarose, $8 \%$ milk, and plasminogen $(2.5 \mathrm{U} / \mathrm{ml}$; Chromogenix, Milan, Italy) and allowed to develop at $37^{\circ} \mathrm{C}$, until dark lysis zones appeared.

Immunoprecipitation. Synaptosomal-enriched plasma membrane was prepared as follows. Mice were perfused with ice-cold PBS, and whole brains were homogenized in 10\% sucrose in 5 mM HEPES buffer, $\mathrm{pH} 7.5$, in the presence of protease inhibitors (Complete, protease inhibitor cocktail tablets; Roche) and then centrifuged for $10 \mathrm{~min}$ at $1000 \times g$. The supernatants were further centrifuged for $20 \mathrm{~min}$ at $12,000 \times g$. The supernatant was removed, and myelin was aspirated from the pellet. The pellet was resuspended in 10\% sucrose HEPES buffer with freshly added protease inhibitors. Immunoprecipitations were performed according to the protocol provided by Santa Cruz Biotechnology (Santa Cruz, CA). Using goat anti-NMDAR $\zeta$ antibody (Santa Cruz Biotechnology) recognizing the $\mathrm{C}$ terminus of the NR1 subunit or the rabbit antitPA antibody (Molecular Innovations, Southfield, MI), immunoprecipitation was performed for $2 \mathrm{hr}$ at $4^{\circ} \mathrm{C}$, followed by adsorption to protein G-Sepharose (Santa Cruz Biotechnology). Bound proteins were eluted in $\beta$-mercaptoethanol containing loading sample buffer and then analyzed by SDS-PAGE electrophoresis on a 7.5\% gel and by immunoblotting.

SDS-PAGE and immunoblot analysis. For the detection of PN-1 in whole-brain homogenates, $15 \mu \mathrm{g}$ of protein was separated on a $12 \%$ SDS-PAGE and transferred onto a Trans-Blot Transfer Medium nitrocellulose membrane (Bio-Rad, Hercules, CA). Membranes were blocked, incubated overnight at $4^{\circ} \mathrm{C}$ with a $\mathrm{PN}$-1-specific mouse monoclonal antibody (1:1000) (Meier et al., 1989) and with a mouse anti-actin antibody (1:1000; NeoMarkers, Fremont, CA). To analyze immunoprecipitates, membranes were blocked and incubated with the goat anti-NMDAR $\zeta$ antibody (C-20) (1:1000; Santa Cruz Biotechnology) for $2 \mathrm{hr}$ at room temperature.

Immunohistochemistry on sections. To detect tPA immunoreactivity in PN-1 KI mice, 50- $\mu$ m-thick cryostat sections were stained with X-gal as described, blocked for $1 \mathrm{hr}$ in 1.5\% normal goat serum, and incubated with the goat anti-tPA primary antibody (1:200; American Diagnostica, Pfungstädt, Germany) for $24 \mathrm{hr}$ at room temperature. The primary antibody was detected with the ABC kit (Santa Cruz Biotechnology) and visualized with diaminobenzidine. For detection of the NR1 subunit, brains from perfusion-fixed wild-type and $\mathrm{PN}-1^{-/-}$littermates (six couples) were postfixed for $2 \mathrm{hr}$ in ice-cold 4\% PFA, equilibrated in 30\% sucrose in PBS overnight, and quickly frozen. Cryostat sections (12 $\mu \mathrm{m})$ from PN-1 ${ }^{-/-}$and wild-type mice were collected on the same slides to ensure identical processing. They were blocked in $1.5 \%$ normal goat serum (Santa Cruz Biotechnology) for $1 \mathrm{hr}$ and incubated with the rabbit anti-NMDAR $\zeta$ antibody (1:400) recognizing the $\mathrm{N}$ terminus of the NR1 subunit for $48 \mathrm{hr}$ at room temperature. The primary antibody was detected using an anti-rabbit biotinylated secondary antibody following the protocol of the manufacturer (Vector Laboratories, Burlingame, CA) and visualized with diaminobenzidine (Sigma, Buchs, Switzerland). Quantitative analysis was performed on five sections per animal selected from every brain on the basis of the same stereotaxic coordinates. Pictures were taken using a Nikon Eclipse E600 microscope with a $10 \times$ objective equipped with a Nikon digital camera, Dxm1200, and analyzed using the Image Pro Plus morphometry software (Media Cybernetics, Silver Spring, MD). The fields were determined using the rectangular field of the camera (representing an area of $1.2 \mathrm{~mm}^{2}$ ), and they included all cortical layers (I-VI), so that the layers were not evaluated separately. For quantification, images were converted to grayscale, and intensity was measured following background subtraction. The threshold was determined so that all labeled cells could be recognized, and the mean intensity per cell was calculated. The analysis was performed blindly of the mouse genotype. Differences in the intensity were analyzed with the Student $t$ 
test. The statistical analysis was performed using the Prism 4 software (GraphPad).

Measurement of synaptic currents. All mice $\left(\mathrm{PN}-1^{-1-}, n=4\right.$; $\mathrm{PN}-$ $1^{+/+}, n=4 ; 4-6$ months of age) were singly housed for several weeks before the experiment. For the recordings, the brains were removed, placed in ice-cold extracellular medium, and $300 \mu \mathrm{m}$ parasagittal slices of primary somatosensory barrel cortex were cut by a vibratome according to standard procedures (Petersen and Sakmann, 2000). The extracellular medium contained the following (in mM): $125 \mathrm{NaCl}, 25 \mathrm{NaHCO}_{3}, 25$ glucose, $2.5 \mathrm{KCl}, 1.25 \mathrm{NaH}_{2} \mathrm{PO}_{4}, 2 \mathrm{CaCl}_{2}$, and $1 \mathrm{MgCl}_{2}$ bubbled with $95 \%$ $\mathrm{O}_{2}$ and $5 \% \mathrm{CO}_{2}$. All experimental procedures were performed at $35^{\circ} \mathrm{C}$. Barrels of the posterior medial barrel subfield were identified in brightfield videomicroscopy at low magnification and a glass patch pipette filled with extracellular solution served as the stimulation electrode and was placed in the center of a layer IV barrel. Stimulation was evoked by $200 \mu \mathrm{sec}$ current pulses of $10-30 \mu \mathrm{A}$. Whole-cell recordings were obtained from layer II/III pyramidal neurons lying in the stimulated barrel column, which were identified by video-enhanced infrared microscopy using the $20 \times 0.95$ numerical aperture water immersion lens of an upright microscope (BX51WI; Olympus, Tokyo, Japan). The intracellular solution contained the following (in mM): 120 Cs-gluconate, 10 HEPES, $10 \mathrm{Na}$-phosphocreatine, $5 \mathrm{CsCl}, 4 \mathrm{MgATP}, 0.3 \mathrm{NaGTP}$, adjusted to $\mathrm{pH}$ 7.2 , with $\mathrm{CsOH}$. Biocytin $(3 \mathrm{mg} / \mathrm{ml})$ was included in the intracellular solution to allow postrecording morphological identification of the recorded neurons. Ionotropic GABAergic synaptic transmission was pharmacologically blocked by either $20 \mu \mathrm{M}$ bicuculline or $100 \mu \mathrm{M}$ picrotoxin, and postsynaptic $\mathrm{GABA}_{\mathrm{B}}$ responses were blocked in the recorded cell by the presence of $\mathrm{Cs}$ in the recording pipette. Synaptic currents evoked by electrical stimulation of layer 4 were recorded with the soma voltageclamped switching between -60 and $+40 \mathrm{mV}$ (to relieve the voltagedependent Mg block of the NMDA receptor). The currents were recorded using Multiclamp 700A amplifiers (Axon Instruments, Foster City, CA) filtered at $2-3 \mathrm{kHz}$ and digitized at $10 \mathrm{kHz}$ using an ITC-18 (InstruTech, Port Washington, NY). EPSCs evoked at $-60 \mathrm{mV}$ were brief and entirely blocked by CNQX $(10 \mu \mathrm{M})$, suggesting that they were mediated exclusively by AMPA/kainate (KA) receptors. Thus, the peak EPSC at $-60 \mathrm{mV}$ provided a measure of synaptically evoked AMPA/KA currents. EPSCs recorded at $+40 \mathrm{mV}$ in general consisted of two components: a long-lasting NMDA receptor-dependent current, which could be blocked by $50 \mu \mathrm{M}$ D-APV leaving a brief EPSC with similar kinetics to those observed at $-60 \mathrm{mV}$ and that could be subsequently blocked by addition of CNQX $(10 \mu \mathrm{M})$. The duration of the AMPA/kainate component was much $<50 \mathrm{msec}$. The long-lasting NMDA component of the EPSC recorded at $+40 \mathrm{mV}$ was therefore quantified at $50 \mathrm{msec}$ poststimulus. Finally, the ratio of NMDA to AMPA/KA currents was computed for each cell to allow statistical comparison between genotypes of cells measured from different brain slices and different animals.

Epicranial sensory-evoked potential recordings. Epicranial recordings of evoked potentials were done essentially as described previously (Troncoso et al., 2000). All mice (PN-1 ${ }^{-/-}, n=4 ; \mathrm{PN}-1^{+/+}, n=4$; males, $4-6$ months of age) were singly housed for at least 2 months before the experiment. Recordings were performed under pentobarbital anesthesia (60 mg/kg, i.p.). Briefly, 10 electromechanical stimuli driven by a computer-controlled signal were applied to whiskers with an interstimulus interval of $3 \mathrm{sec}$. An array of five electrodes $(0.45 \mathrm{~mm}$ in external diameter and $2 \mathrm{~cm}$ length) was placed above the skull. The pertinent electrodes positioned in a row had the following coordinates relative to bregma: anteroposterior (AP), 1/1 2.5; AP, 2/1 3.0; and AP, 3/l 3.5 (distances in millimeters). Signals were amplified (10,000 times) and filtered (high-pass, $4 \mathrm{~Hz}$; low-pass, $300 \mathrm{~Hz}$ ) and then hooked up and digitally converted (16 bits; $2 \mathrm{kHz}$ with triggered scan) and stored for post hoc analysis. For the activation, whiskers were stimulated unilaterally at $8 \mathrm{~Hz}$ during a period of $10 \mathrm{~min}$. The responses after activation represent the mean of three series of three recordings at $10 \mathrm{~min}$ intervals. For data analysis, the signal-processing technique of statistical outlier elimination excluded samples fulfilling the rejection criteria (beyond two SDs from the original mean). The overall mean of the three recording series calculated after signal processing was taken as the result of each experimental condition ( $\sim 20$ responses). Then, the peak positive $(\mathrm{P})$ and negative $(\mathrm{N})$ values $10-30 \mathrm{msec}$ poststimulus were measured. For the treatment with (+)-5-methyl-10,11-dihydro-5H-dibenzo [a,d] cyclohepten-5,10-imine maleate (MK-801), different doses $(0.3,0.4,0.5$, and $0.6 \mathrm{mg} / \mathrm{kg}$, i.p.) were tested in a first group of eight C57BL/6 mice to observe their tolerance with pentobarbital anesthesia. Two additional groups of C57BL/6 mice $(n=5)$ were compared, one of which received a dose of $0.3 \mathrm{mg} / \mathrm{kg}$ MK-801 $30 \mathrm{~min}$ before pentobarbital anesthesia. This dose gave reproducible results, and all animals survived and recovered normally. The effect lasted for $>90$ min before animals started to recover from anesthesia. Recordings were obtained $60 \mathrm{~min}$ after induction of pentobarbital anesthesia and $90 \mathrm{~min}$ after MK-801 was administered.

Gap-crossing test. The effective use of mice whiskers $\left(\mathrm{PN}-1^{-1-}, n=\right.$ 12 ; $\mathrm{PN}-1^{+/+}, n=11$; females, $4-6$ months of age, single housed for at least 2 months) was tested in a modified gap-crossing paradigm (Barneoud et al., 1991). All training and testing was performed blind by a single experimenter during the dark cycle under dim illumination (10 lux), and the testing was videotaped. Mice were trained 1 week before the start of the experiment to become accustomed to the apparatus $[10 \times 20$ $\mathrm{cm}$ carrying box; a movable platform $(6 \times 6 \mathrm{~cm})$ set against the escape tube (54 $\mathrm{mm}$ inner diameter, $12 \mathrm{~cm}$ in length, the first $6 \mathrm{~cm}$ transparent)]. The experiment consisted of four trials. For trial 1 (training trial), each mouse was transferred to the platform placed $2 \mathrm{~cm}$ from the tube and retested after $120 \mathrm{sec}$ if it did not cross the gap. The gap was incrementally increased until the animal balked. Trial 2 was started after $1 \mathrm{~d}$ of rest. Animals were tested as above, and the latency to jump was noted. Trial 3 was started at least 1 week later. The animals were tested as for trial 2 but were given a second chance at each distance if they did not jump by $15 \mathrm{sec}$, and the maximum gap crossed was noted. On the day after trial 3 , the mice were briefly anesthetized in metofane and their whiskers trimmed. Trial 4, a repeat of trial 3, took place the following day. The latency (the time to jump a particular distance with a maximal score of 15 $\mathrm{sec}$ ) from trial 2 was analyzed by two-way ANOVA [with distance as the within-subjects (repeated measure) variable and genotype as the between-subjects variable]. The difference between the maximum distance crossed before and after cutting the whiskers in trials 3 and 4 was analyzed by the Wilcoxon signed rank test.

Locomotor activity was examined as described previously (Meins et al., 2001) by placing mice individually in one corner of a perspex box $(40 \times 40 \mathrm{~cm})$ with a total of 16 squares $(10 \times 10 \mathrm{~cm})$. The number of squares crossed (at least two paws entering a square) and the number of rears made in $6 \mathrm{~min}$ were recorded. All analyses were performed using the Prism 4 (GraphPad) statistical package.

\section{Results}

\section{The $\mathrm{PN}-1 \mathrm{KI}$ reporter mouse}

To study activity-dependent expression of PN-1, we generated mice with a reporter gene following the $\mathrm{PN}-1$ coding sequence. A targeting vector containing the cDNA for the HA-tagged PN-1 and $\beta$-galactosidase, separated by an IRES, was inserted into exon II of the $P N-1$ gene, placing it under the transcriptional control of the $\mathrm{PN}-1$ promoter (Fig. $1 A$ ). Four PCR primers were used to screen for construct insertion (Fig. $1 B$ ) to distinguish between homozygote and heterozygote mice.

We examined basal PN-1 expression by monitoring $\beta$-galactosidase levels in sagittal sections (Fig. $1 C$ ). It was particularly prominent in the inferior colliculus, in parts of the visual system such as the visual cortex and anterior pretectal nucleus, and in the periglomerular cells of the olfactory bulb. $\beta$-Galactosidase activity was also high in layer $\mathrm{V}$ of the cortex, some thalamic nuclei, the caudate-putamen, and several nuclei of the brain stem. In the cerebellum, PN-1 expression was almost completely confined to the Purkinje cells. This expression profile was in accordance with in situ hybridization data (Mansuy et al., 1993), confirming that the insert was under the control of the PN-1 promoter. 

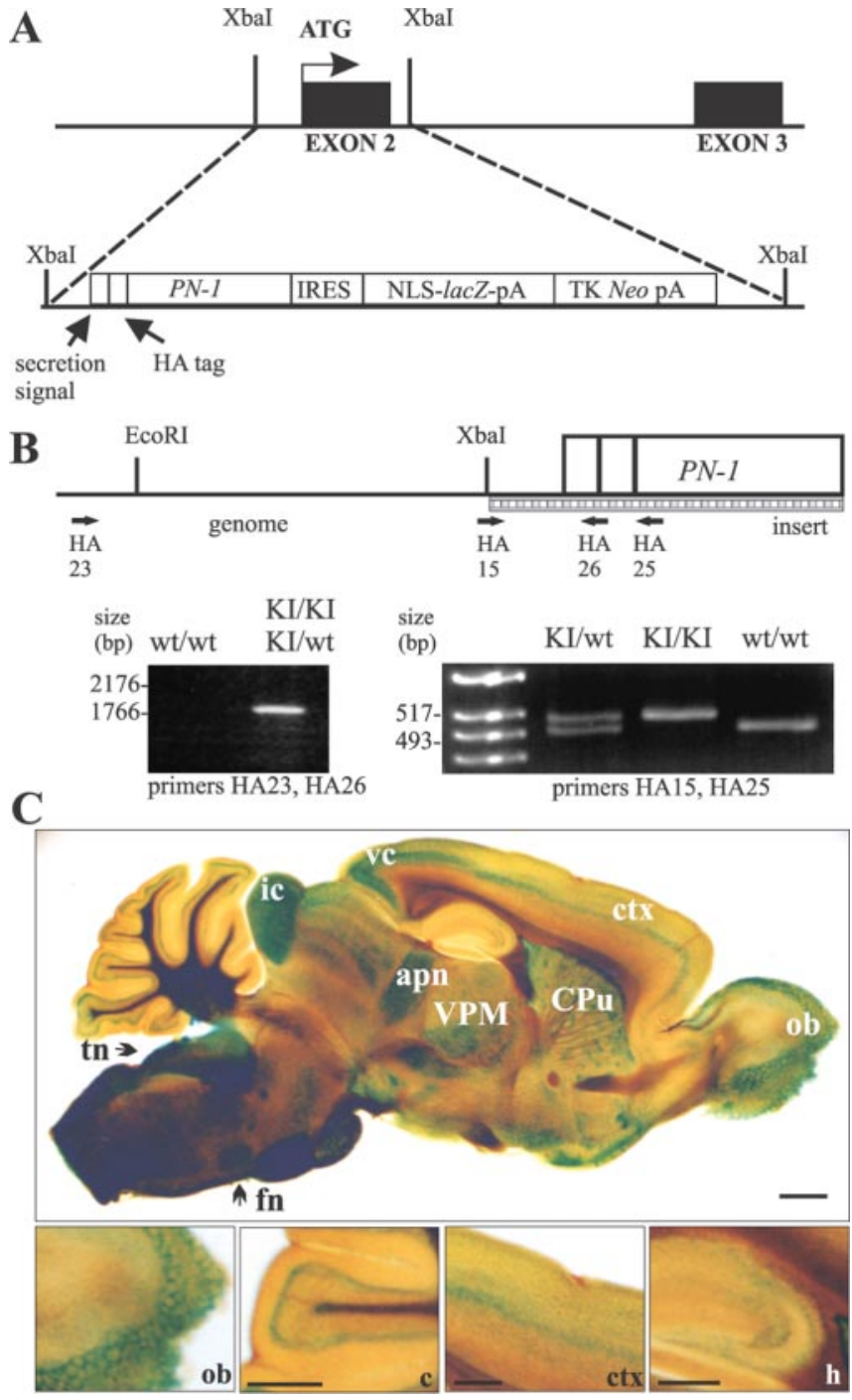

Figure 1. Generation and characterization of the PN-1 KI mouse. A, Top, Schematic representation of the PN-1 genomic locus with relevant restriction enzyme sites. The translational start site is marked by the arrow. Bottom, Targeting vector. The elements of the construct are shown as open boxes. ATG, Start codon. B, Top, Schematic representation of the annealing locations of $\mathrm{PCR}$ primers used for the genotyping of PN- $1 \mathrm{KI}$ mice. The directions of the primers are indicated by arrows. Bottom, PCR analysis of genomic DNA from a litter of a heterozygous cross, using primers HA23 and HA26 (left) and HA15 and HA25 (right) (see Materials and Methods). C, PN-1 expression in the adult mouse brain. Note the strong expression in the olfactory bulb (ob), cortical layers (ctx), visual cortex (vc), inferior colliculus (ic), caudate-putamen (CPu), VPM, anterior pretectal nucleus (apn), trigeminal nucleus (tn), and facial nucleus (fn). Enlargements (bottom) show the cellular localization of the expression in the olfactory bulb, cerebel$\operatorname{lum}(\mathrm{c})$, cortex (ctx), and hippocampus (h). Scale bars: (in C) top, $1 \mathrm{~mm}$; (in c) bottom, ob, c, 500 $\mu \mathrm{m} ;$ (in h) ctx, h, $500 \mu \mathrm{m}$.

\section{Short-term whisker deprivation and PN-1 upregulation}

To determine the effects of changed sensory experience on PN-1 expression and its influence on the function of sensory pathways, we used the whisker-to-barrel cortex pathway, a system with numerous advantages for such studies, because it gives the opportunity for nonintrusive and specific modifications of the sensory input (Barth et al., 2000; Fox, 2002; Knott et al., 2002) and a one-to-one functional and topological correspondence between whiskers and specific groups of neurons in the somatosensory cortex (Woolsey and Van der Loos, 1970).

PN-1 KI mice were unilaterally deprived of all but the D1 whisker and placed in a sensory enriched environment for a pe- riod of $24 \mathrm{hr}$ to encourage whisker-dependent exploration. Single-whisker experience was previously used to study activitydependent expression of proteins (Barth et al., 2000; Staiger et al., 2000) and was shown to induce plasticity in the barrel cortex (Barth et al., 2000; Fox, 2002). Whole-mount brain X-gal histochemistry revealed a localized upregulation of $\beta$-galactosidase in the cortex contralateral to the spared whisker, visible as a blue dot (Fig. 2A, arrow). X-gal histochemistry on coronal sections showed that the upregulation was located within layers II/III and $\mathrm{Vb}$ (Fig. 2 B, C con, arrows; supplemental material, available at www.jneurosci.org). The upregulation in layer II/III appeared to be restricted to a population of cells identified by their small nuclei (Fig. 2 D), suggesting that $\mathrm{PN}-1$ expression was triggered in previously nonexpressing cells. PN-1 expression remained unchanged in the hemisphere contralateral to the intact whiskers. This fits well with publications showing that, during singlewhisker experience, the undeprived control side shows normal levels of activation (Barth et al., 2000; Fox, 2002). This indicates that PN-1 upregulation requires the potentiation of the spared vibrissae.

Seventy-two hours of single-whisker experience induced a stronger PN-1 upregulation, which spread to other cortical layers (Fig. $2 E$, arrow) and was particularly prominent in layers IV and $\mathrm{Vb}$ (Fig. $2 \mathrm{~F}$, arrows). The upregulation was also found in several thalamic nuclei belonging to the major projections of the whisker pathway. The ventral posterior medial nucleus (VPM) and the contralateral posterior nucleus ( $\mathrm{Po}$ ) showed the strongest signal, but the upregulation was also present in the ventral posterior lateral thalamic nucleus (VPL) (Fig. $2 E$ ). It has been shown that 1 $\mathrm{hr}$ of single-whisker experience can induce a rapid upregulation of transcription factors in the barreloids of the VPM (Bisler et al., 2002), but PN-1 upregulation was more widespread, possibly because of a longer period of changed sensory experience. The VPL is considered to receive somatosensory inputs from the body and limbs. At present, we cannot explain the PN-1 upregulation in this nucleus, but we can provide some possible explanations. First, during single-whisker experience mice might groom the whisker pad more intensively, thus unilaterally stimulating the sensory pathway of the corresponding front paw. Second, a previous report (Arnold et al., 2001) shows direct connections between the VPL and the barrel columns, which could be pertinent.

If single-whisker experience was performed for $24 \mathrm{hr}$, but without exposure to enriched environment, specific $\beta$-galactosidase upregulation could still be detected (Fig. 2G, arrow), showing that PN-1 expression can be triggered in control housing conditions as well.

To determine whether brain stem structures of the whisker pathway also exhibited activity-dependent PN-1 expression, all whiskers on one side of the head were removed, and mice were exposed to $72 \mathrm{hr}$ of enriched environment. Compared with control mice (Fig. 2 H, I, right), a strong unilateral upregulation, ipsilateral to the side with intact whiskers, was detected in the facial nucleus, spinal trigeminal nucleus oralis (Fig. $2 \mathrm{H}$, left, arrow and arrowhead, respectively), and in the spinal trigeminal nucleus interpolaris (Fig. 2I, left, arrowhead).

Because tPA is one of the target proteases of PN-1 (Scott et al., 1985), we examined whether cells upregulating PN-1 also express tPA. The majority of these cells in layers II/III were positive for tPA (Fig. $3 A, B$, filled arrowheads) as well as some pyramidalshaped cells in layer V (Fig. 3C). Furthermore, we investigated the identity of PN-1 upregulating cells using cell type-specific markers and found that these cells do not belong to pyramidal neu- 
rons, GABAergic inhibitory neurons, or GFAP-positive glial cells (supplemental material, available at www.jneurosci.org).

In summary, these results show that a restricted subpopulation of cells within the somatosensory cortex upregulates $\mathrm{PN}-1$ expression after neuronal activity in sensory conditions that induce plasticity.

\section{Changes in brain proteolytic activity and NMDA receptors in $\mathrm{PN}-1^{-/-}$mice} Because $\mathrm{PN}-1$ is a potent inhibitor of serine proteases (Scott et al., 1985), we investigated whether its absence leads to changes in brain proteolytic activity. Measurements in whole-brain homogenates, using the broad-spectrum chromogenic substrate S-2288, revealed significantly higher levels of proteolytic activity $\left(\mathrm{mOD}_{405} / \mathrm{min}\right)$ in $\mathrm{PN}-1^{-1-}$ mice compared with their wild-type littermates $(0.09 \pm 0.009$ vs $0.24 \pm 0.061$; Student's $t$ test, ${ }^{\star} p=0.0495$ ) (Fig. $4 A$ ). This activity could be inhibited to wild-type levels by 0.25 mM tPA-STOP, a synthetic tPA inhibitor (data not shown). In situ zymography on cortical sections revealed increased tPA activity, visible as dark lysis zones, in the cortex of PN-1 $1^{-1-}$ mice (Fig. $4 B$ ). A control zymography on sections from $\mathrm{tPA}^{-/-}$ mice did not reveal any proteolytic activity (data not shown).

Because in vitro NMDA receptor signaling can be modified by the tPAmediated cleavage of the NR1 subunit (Nicole et al., 2001) or activation of the LRP receptors (Bacskai et al., 2000; Qiu et al., 2002), we investigated whether the increased proteolytic activity in the brains of $\mathrm{PN}-1^{-1-}$ mice is correlated with changes in the NR1 subunit in vivo. Immunohistochemistry performed in identical conditions (see Materials and Methods) on sections from PN-1 ${ }^{-1-}$ and wild-type mice, detecting the extracellular part of the NR1 subunit, showed a markedly reduced immunoreactivity in the somatosensory cortex (Fig. $4 C, D)$ and in the hippocampus (data not shown) of $\mathrm{PN}-1^{-1-}$ mice. Immunoprecipitation and Western blot analysis with an antibody against the $\mathrm{C}$ terminus of NR1 also revealed decreased NR1 levels in synaptosomal fractions from PN-1 $1^{-1-}$ mice (Fig. $4 E$ ). Because a direct interaction between tPA and NR1 has been shown previously (Nicole et al., 2001), we performed immunoprecipitations against tPA followed by Western blot analysis with an anti-NR1 antibody. More NR1 was coprecipitated in PN-1 ${ }^{-/-}$ mice (Fig. $4 F$ ), suggesting an increased interaction between tPA and NR1 because of the higher levels of active tPA. Altogether, these results indicate that the in vivo availability of the NR1 subunit of the NMDA receptor requires a tight control of brain proteolytic activity.

\section{Modified proteolytic activity and NMDA receptors in $\mathrm{PN}-1^{-/-}$ mice after exposure to enriched environment}

To determine whether these changes in the control of proteolytic activity and the availability of the NR1 subunit can also be influ-
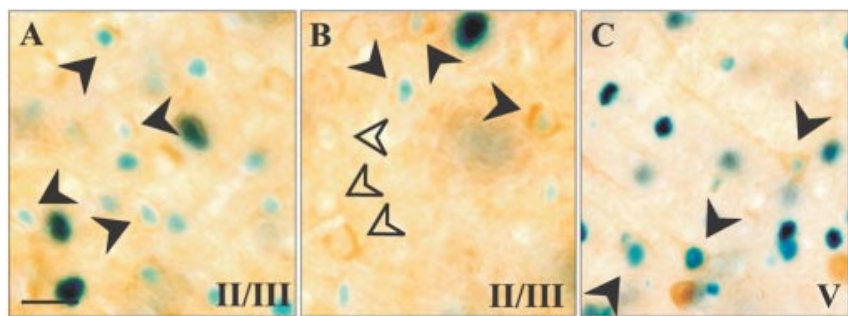

Figure 3. tPAimmunoreactivity in cells upregulating PN-1. A, B, Combined X-gal histochemistry and TPA immunohistochemistry revealed a colocalization in layer II/III cells upregulating PN-1 after $24 \mathrm{hr}$ of single-whisker experience (filled arrowheads). PN-1 upregulating cells are distinguished by their small, light blue nuclei, and TPA immunoreactivity is visible as brown membrane staining. Some cells of layer II/IIl expressed tPA but not PN-1 (open arrowheads). $C$, In layer V, some cells expressing PN-1 also expressed tPA (arrowheads). Scale bar: (in A) A-C, 50 $\mu \mathrm{m}$.

enced by a generalized complex stimulus, wild-type mice were exposed to $24 \mathrm{hr}$ of enriched environment, known to induce neuronal activity, and widespread plastic responses (van Praag et al., 2000). A Western blot against PN-1, performed on wholebrain homogenates, revealed a strong increase in $\mathrm{PN}-1$ protein amounts in enriched mice (Fig. 5A). Next, we investigated 
A

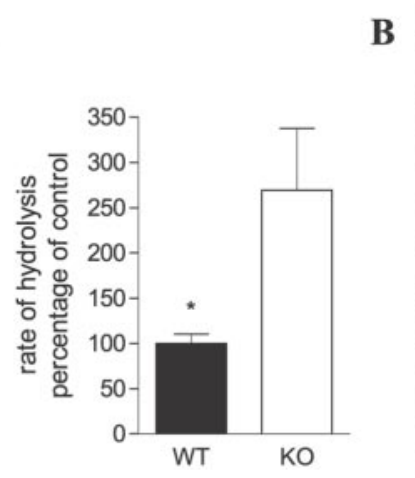

C
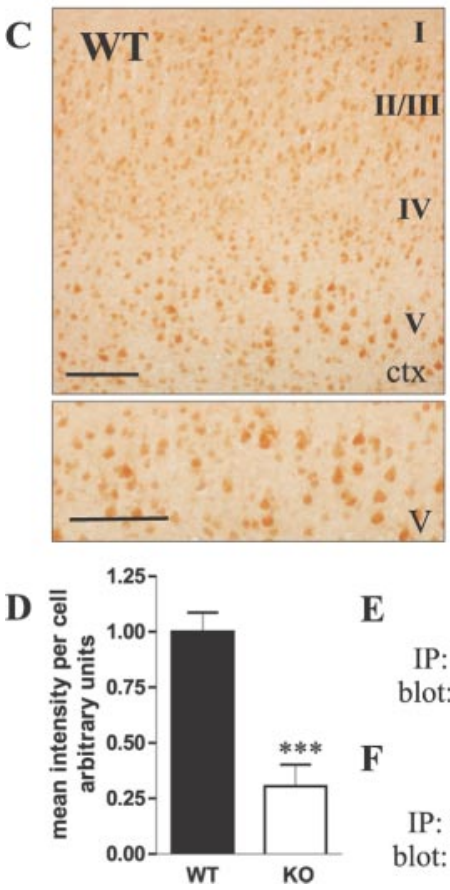

$\mathbf{E}$ IP: NR1 blot: NR1

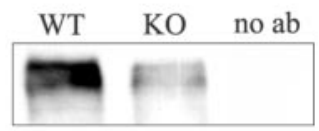

$\mathbf{F}$ IP: tPA
blot: NR1

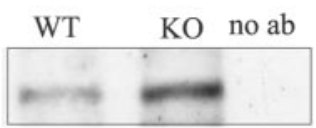

Figure 4. Changes in brain proteolytic activity and NMDA receptors in $\mathrm{PN}-1^{-/-}$mice. $A$, Proteolytic activity in brain homogenates, showing increased brain proteolytic activity in PN$1^{-I-}$ mice $(\mathrm{KO} ; n=4)$, compared with wild-type littermates (WT; $\left.n=4\right)$. Values are mean \pm SEM. Equal amounts of protein were tested, and the rate of hydrolysis from wild-type mice was set to $100 \%\left(0.09 \mathrm{m0D}_{405} / \mathrm{min}\right) . B$, In situ zymography showing stronger tPA activity (dark lytic zones) in cortical sections from PN-1 ${ }^{-1-}$ mice. The cortical layers location was visualized by cresyl violet staining on adjacent sections (data not shown). C, A prominent decrease in NR1 immunoreactivity in cortical sections from $\mathrm{PN}-1^{-1-}$ mice (quantification in $D ; * * * 0=0.0003$ ) also found in the immunoprecipitation and Western blot analysis of synaptosomal fractions $(E)$. $F$, In PN-1 ${ }^{-I-}$ mice, more NR1 was coimmunoprecipitated with an antibody against tPA. For each experiment, a representative of three independent experiments is shown. Scale bars: $B$, $150 \mu \mathrm{m} ; C, 100 \mu \mathrm{m}$. ctx, Cortex; II/III, V, cortical layers.

whether increased $\mathrm{PN}-1$ protein levels changed the brain proteolytic activity. Strikingly, a strong decrease in proteolytic activity $\left(\mathrm{mOD}_{405} / \mathrm{min}\right)$ was found after $24 \mathrm{hr}(0.104 \pm 0.0084$ vs $0.051 \pm$ 0.0035 ; Student's $t$ test, $\left.{ }^{* *} p=0.0043\right)$ and $72 \mathrm{hr}$ of enriched environment $(0.1075 \pm 0.0045$ vs $0.069 \pm 0.0038$; Student's $t$ test, ${ }^{*} p=0.008$ ) (Fig. 5B). Measurements performed with a thrombin-specific chromogenic substrate revealed no change in thrombin-like activity (data not shown). To verify that tPA activity was affected by enriched environment, we analyzed our samples by gel zymography (Lantz and Ciborowski, 1994). Only one band of proteolytic activity, corresponding to the size of recombinant tPA, was visible (data not shown).

To further examine the link between PN-1 and the activity- dependent regulation of proteolytic activity, $\mathrm{PN}-1^{-1-}$ mice were exposed to $24 \mathrm{hr}$ of enriched environment. Compared with PN$1^{-1-}$ mice housed in control conditions, a marked increase in proteolytic activity $\left(\mathrm{mOD}_{405} / \mathrm{min}\right)$ was detected $(0.163 \pm 0.008$ vs $0.33 \pm 0.028$; Student's $t$ test, ${ }^{* *} p=0.005$ ) (Fig. $5 C$ ). An in situ zymography on cortical sections from wild-type and $\mathrm{PN}-1^{-/-}$ mice exposed to enriched environment also showed a strong upregulation of activity in $\mathrm{PN}^{-1}{ }^{-/}$mice (Fig. $5 D$ ). Because the expression and release of serine proteases can be enhanced by neuronal activity (Seeds et al., 1995; Pawlak et al., 2003), these findings indicate a perturbed control of activity-dependent brain proteolytic activity in $\mathrm{PN}-1^{-1-}$ mice.

Next, we investigated whether increased proteolytic activity in $\mathrm{PN}-1^{-1-}$ mice exposed to enriched environment leads to additional changes in the NR1 subunit of the NMDA receptor. Immunohistochemistry on cortical sections (Fig. $5 E$, quantitation in $F$ ) and western-blot analysis of synaptosomal fractions (Fig. 5G), revealed decreased NR1 immunoreactivity in enriched $\mathrm{PN}-1^{-1-}$ mice, compared with $\mathrm{PN}^{-1}{ }^{-/}$mice housed in control conditions. In wild-type mice, exposure to enriched environment slightly increased NR1 immunoreactivity (Fig. $5 \mathrm{H}$, J, quantification in $I$ ).

\section{NMDA receptor-dependent synaptic currents in the barrel cortex}

To substantiate a deficiency in NMDA receptor function, NMDA receptor-dependent synaptic currents were measured in the barrel cortex of $\mathrm{PN}-1^{-1-}$ mice and their wild-type littermates (Fig. $6 A, B)$. An extracellular stimulation electrode was placed in the center of a layer IV barrel, and evoked EPSCs were recorded in layer II/III pyramidal neurons. EPSCs recorded at $-60 \mathrm{mV}$ were dominated by AMPA/KA-mediated currents, which could be completely blocked by $10 \mu \mathrm{M}$ CNQX, and the peak EPSC provided a measure of AMPA/KA receptor component of the EPSC. The EPSC at $+40 \mathrm{mV}$ had an early component mediated by AMPA/KA receptors and a late component reflecting NMDA receptor-dependent currents. Quantified at 50 msec poststimulus, the EPSC was entirely dependent on currents through NMDA receptors (they could be blocked by $50 \mu \mathrm{M}$ D-APV), and this provided a measure of the NMDA receptor component of the evoked EPSC. The membrane potential was alternated between -60 and $+40 \mathrm{mV}$, and the ratio of NMDA receptor-dependent to AMPA/KA receptor-dependent current was calculated for each experiment. Figure $6 \mathrm{~A}$ shows an example of EPSCs recorded in a PN-1 $1^{+/+}$and $\mathrm{PN}-1^{-1-}$ mouse. In the wild type, the EPSC recorded at $-60 \mathrm{mV}$ lasts a few tens of milliseconds and is mediated by AMPA/KA receptors. The EPSC recorded at $+40 \mathrm{mV}$ is much longer lasting, and the late component ( $>40 \mathrm{msec}$ ) is mediated almost exclusively by NMDA receptors. In $\mathrm{PN}-1^{-1-}$ mice, the EPSC recorded at $-60 \mathrm{mV}$ was similar to WT animals, showing rapid kinetics and complete dependence on AMPA/KA receptors. The EPSC kinetics recorded in these animals at $+40 \mathrm{mV}$ were similar to those recorded at $-60 \mathrm{mV}$, in contrast to WT mice which showed a prominent long-lasting NMDA receptordependent component at $+40 \mathrm{mV}$. The ratios between $\mathrm{PN}-1^{-1-}$ and $\mathrm{PN}-1^{+/+}$mice were statistically different (Fig. $6 B$ ) (Student's $t$ test, $p<0.01$ ), with the $\mathrm{PN}-1^{+/+}$having an NMDA/AMPA ratio of $0.91 \pm 0.18$ and the $\mathrm{PN}-1^{-1-}$ having a ratio of $0.32 \pm$ 0.07 . Thus, the data show that $\mathrm{PN}^{-1-}$ mice are deficient in functional NMDA receptors relative to functional AMPA/KA receptors at excitatory synapses of the barrel cortex. 


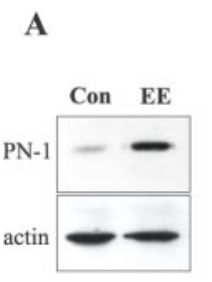

C

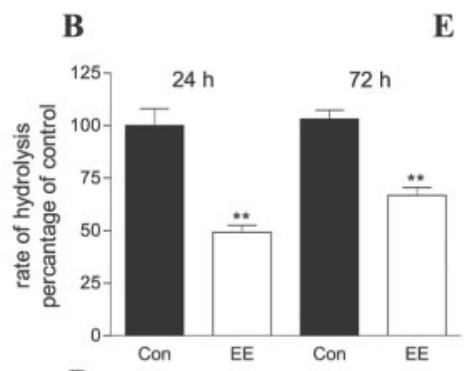

D

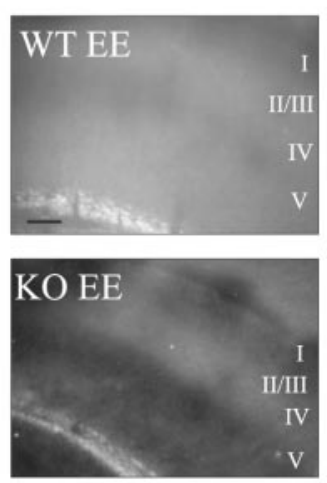

E

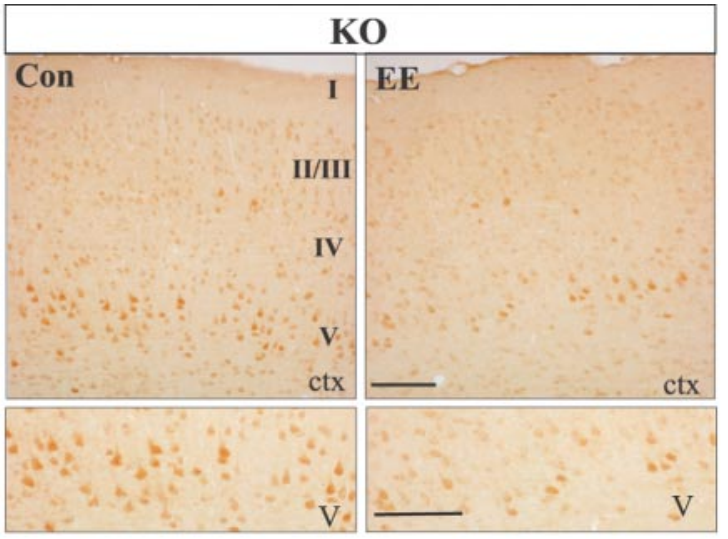

$\mathbf{H}$

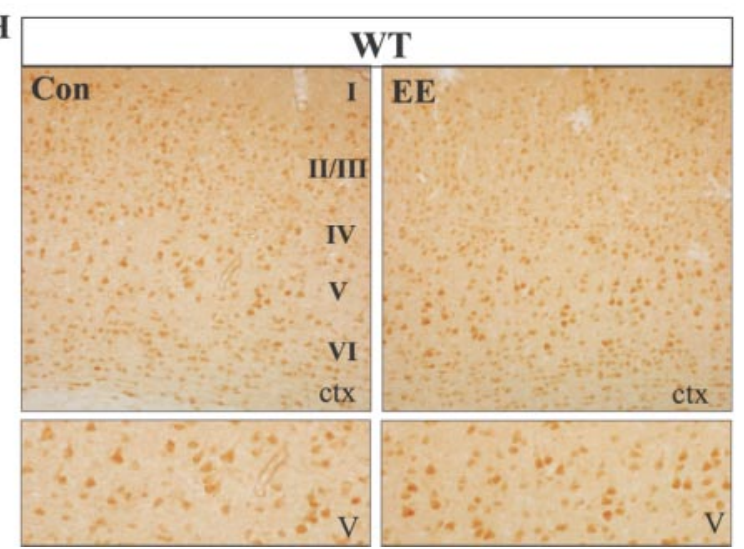

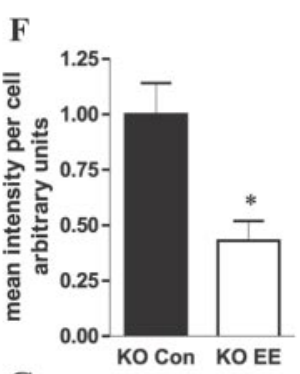

G

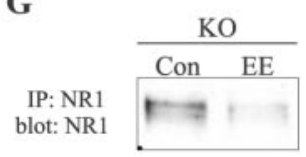

I

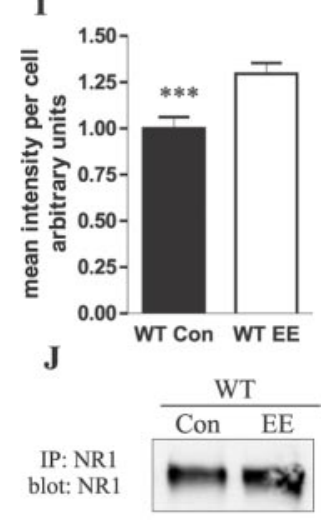

Figure 5. Changes in brain proteolytic activity and NMDA receptors after enriched environment. $A$, Increased PN-1 protein levels in brain homogenates from wild-type mice housed in the enriched environment (Con, control). B, Proteolytic activity in the same brain homogenates was significantly decreased after housing in the enriched environment (EE $24 \mathrm{hr}, n=3 ; \mathrm{EE} 72 \mathrm{hr}, n=3 ;$ Con, $n=$ 3). Equal amounts of protein were tested, and the rate of hydrolysis from wild-type mice was set to $100 \%\left(0.1075 \mathrm{mOD}{ }_{405} / \mathrm{min}\right)$. Values are mean $\pm \mathrm{SEM}$. C, When exposed to enriched environment, $\mathrm{PN}-1^{-1-}$ mice (EE; $\left.n=3\right)$ showed increased brain proteolytic activity, compared with control-housed PN-1 ${ }^{-1-}$ mice $\left(C_{0 n} ; n=3\right)\left(100 \%=0.163 \mathrm{~m} 0 \mathrm{D}_{405} / \mathrm{min}\right) . D$, In situ zymography showing increased proteolytic activity in the cortex of PN-1 ${ }^{-1-}$ mice housed in the enriched environment. The cortical layers location was visualized by cresyl violet staining on adjacent sections (data not shown). E, Enriched environment induced a decrease in the NR1 subunit immunoreactivity in the cortex (quantification in $F$; $^{*} p=0.0168$ ) and in synaptosomal fractions ( $G$ ) of PN ${ }^{-I-}$ mice but not in wild-type mice, where the immunoreactivity was slightly increased $\left(H ;\right.$ quantification in $\left.I^{* * *} p=0.0006 ; J\right)$. Representatives of three independent experiments are shown. WT, PN- ${ }^{+} /+{ }_{\text {mice; }}$ KO, PN-1 ${ }^{-1-}$ mice. Scale bars: D, $150 \mu \mathrm{m}$; (in $\left.E\right) E, H, 100 \mu \mathrm{m}$. ctx, Cortex; II/III, V, cortical layers.

\section{Sensory-evoked potential recordings in the somatosensory cortex}

$\mathrm{PN}-1^{-1-}$ mice appeared to have a normal barrel field cytoarchitecture, as revealed in tangential sections through layer IV by cytochrome oxidase staining (data not shown). To find out whether decreased NMDA receptor signaling in the somatosensory cortex of $\mathrm{PN}-1^{-1-}$ mice had an impact on cortical physiology, we measured cortical responses to whisker stimulation. Primary SEPs were simultaneously recorded over the contralateral anterior and posterior barrel cortex and the auditory cortex using a noninvasive epicranial array of three electrodes (Troncoso et al., 2000; Meins et al., 2001; Troncoso et al., 2004). For the analysis, we focused on the early positive and negative responses obtained $\sim 13$ and $\sim 25$ msec after stimulation. A typical waveform of SEP recorded at $-1 \mathrm{~mm}$ behind bregma (over the anterior barrel cortex) is shown in Figure 6C. The amplitude of field macropotentials in $\mathrm{PN}-1^{-1-}$ mice was lower than in wild-type littermates, whereas the latencies were not different. Slopes $(\mu \mathrm{V} / \mathrm{msec})$ measured from peak $\mathrm{P}$ and $\mathrm{N}$ values revealed that sensory activity in $\mathrm{PN}-1^{-1-}$ mice was significantly decreased over the barrel cortex (at $-2 \mathrm{~mm}$ behind bregma, $40.8 \pm 2.9$ vs $28.7 \pm 3.4,{ }^{*} p=0.034$; at $-1 \mathrm{~mm}$ behind bregma $30.4 \pm 1.9$ vs $11.8 \pm 1.1,{ }^{* *} p=0.002$ ) (Fig. 6D). Responses obtained at $-3 \mathrm{~mm}$ were similar in PN$1^{-I-}$ and $\mathrm{PN}_{-1} 1^{+/+}$mice. These were considered auditory responses because of their anatomical location and because they were recorded in response to the stimulator click, even without whisker deflection (data not shown).

To test the hypothesis that the lower SEPs in $\mathrm{PN}^{-} 1^{-1-}$ mice could be caused by a deficiency in NMDA receptor transmission, SEPs were recorded in wild-type C57BL/6 mice, which received MK-801, an irreversible, high-affinity, noncompetitive NMDA receptor antagonist. NMDA receptor inhibition that resulted in a flattening of SEP values (Fig. $6 E)$ and slopes $(\mu \mathrm{V} / \mathrm{msec}$ ) revealed that sensory activity in treated mice was significantly decreased $\left(28.6 \pm 1.9\right.$ vs $\left.18.7 \pm 2.8 ;{ }^{*} p<0.01\right)$ (Fig. $\left.6 F\right)$. Ketamine, another specific, noncompetitive NMDA receptor blocker, produced an even more pronounced effect at subanesthetic doses (data not shown). Thus, NMDA receptors appear to be crucial for the generation of SEP in wild-type mice, suggesting that the smaller SEPs in $\mathrm{PN}-1^{-1-}$ mice could reflect a deficiency in NMDA receptordependent synaptic transmission.

\section{Assessment of whisker-dependent sensory motor function in PN-1 ${ }^{-1-}$ mice}

Because the barrel cortex is crucial for whisker function (Hutson and Masterton, 1986), we tested the performance of $\mathrm{PN}-1^{-1-}$ mice in a whisker-dependent task, in which mice have to cross a gap of increasing width. Such a test has been used previously to assess the behavioral consequences of barrel cortex lesions on whisker function (Barneoud et al., 1991; Jenkinson and Glick- 


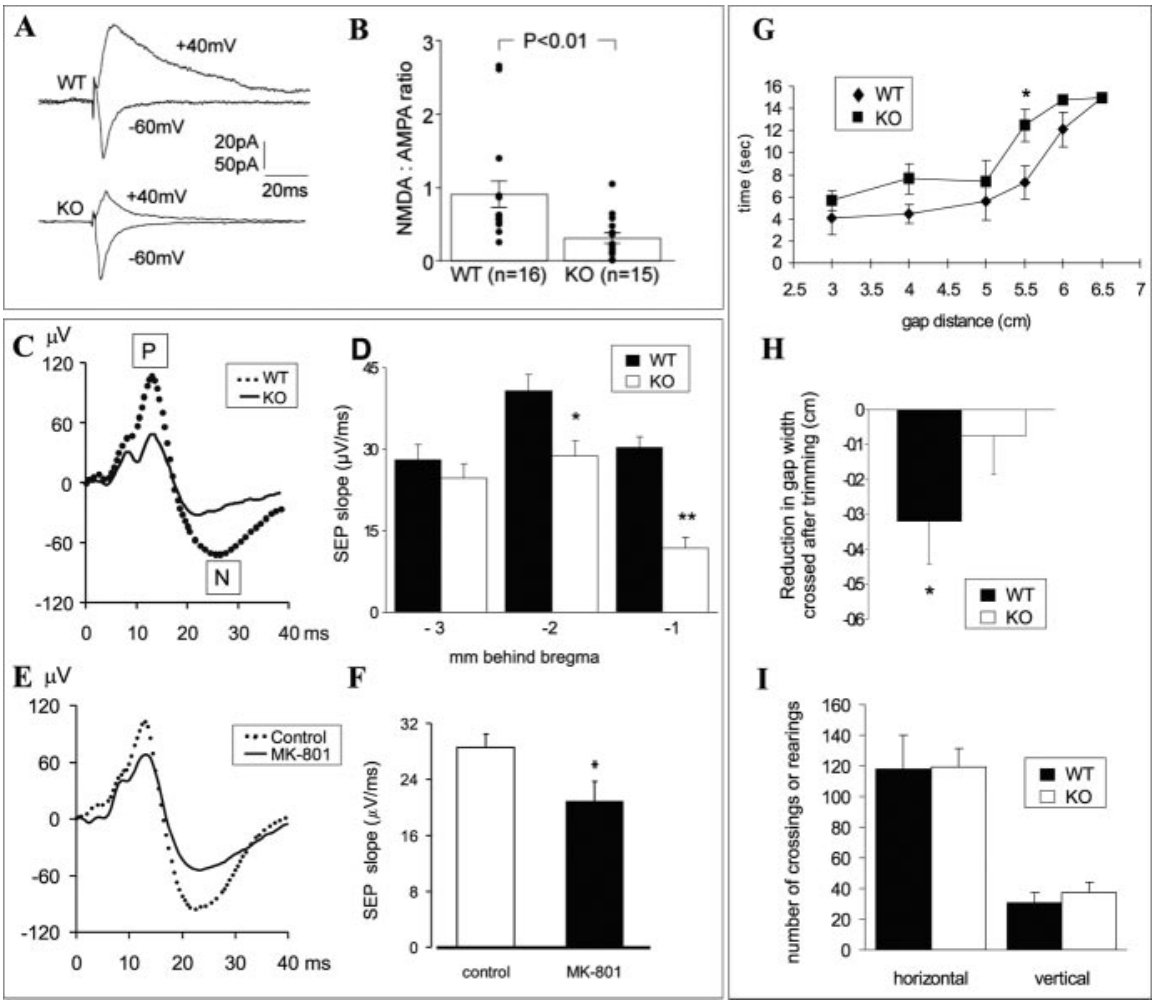

Figure 6. Alterations of NMDA receptor-dependent synaptic currents, sensory-evoked potentials, and whisker-dependent sensory motor function in $\mathrm{PN}-1^{-/-}$mice. $A$, An example of a synaptic current measurement in a PN-1 ${ }^{+/+}$(WT) and a PN-1 ${ }^{-1-}$ mouse (KO). Note the strong reduction in the EPSCs recorded at $+40 \mathrm{mV}$ in the PN-1 ${ }^{-1-}$ mouse. $B$, Reduced NMDA receptordependent synaptic currents, relative to AMPA/kainate receptor-dependent currents in $\mathrm{PN}-1^{-1-}$ mice. Each point represents an individual cell ( $n=16, \mathrm{WT} ; n=15, \mathrm{KO})$. C, Typical waveform of SEPs recorded at $-1 \mathrm{~mm}$ behind bregma, showing lower amplitude of field macropotentials in PN-1 ${ }^{-1-}$ mice. D, Decreased SEPs in the posterior $(-2 \mathrm{~mm}$ behind bregma) and anterior $\left(-1 \mathrm{~mm}\right.$ behind bregma) barrel cortex of PN- $1^{-1-}$ mice $(n=4)$, compared with PN- $1^{+/+}$mice $(n=4)$. Auditory responses at $-3 \mathrm{~mm}$ were not different. $E$, Effect of pharmacological blocking of NMDA receptors in wild-type mice on SEP amplitude in the barrel cortex. F, Decreased SEP in wild-type mice treated with MK-801 $(n=5)$, compared with nontreated control mice $(n=5)$. $G, \mathrm{PN}-1^{-1-}$ mice $(n=11)$ need significantly more time to perform a whisker-dependent task than their wild-type littermates $(n=11)$; values are the mean crossing time (up to $15 \mathrm{sec}) \pm$ SEM. $H$, When tested for the maximal distance crossed before and after whisker trimming, wild-type littermates $(n=11)$, but not PN-1 ${ }^{-1-}$ mice $(n=12)$, crossed shorter distances when deprived of whiskers; values are the difference in the mean distance crossed within 15 sec before and after the trim \pm SEM. I, No differences were found in open-field activity between $\mathrm{PN}-1^{-1-}$ mice $(n=11)$ and their wild-type littermates $(n=11)$.

stein, 2000; Troncoso et al., 2004). Both genotypes displayed a distance-dependent delay in crossing the gap $\left(F_{(1,20)}=21.58 ; p<\right.$ $0.0001)$, but $\mathrm{PN}-1^{-1-}$ mice needed more time to perform the task $\left(F_{(1,20)}=8.51 ; p<0.005\right.$; post-test, $\left.t=2.84 ;{ }^{\star} p<0.05\right)$ (Fig. $\left.6 G\right)$. The slope of the performance curves changed noticeably after 5 $\mathrm{cm}$, consistent with the idea that parameters such as whisker input influencing performance come into play with increasing distance (Barneoud et al., 1991).

To find out how much $\mathrm{PN}-1^{-1-}$ mice rely on their whiskers, we tested their ability to perform the task after complete whisker trimming. As expected, the trimming strongly impaired the performance of wild-type mice $\left(0.318 \pm 0.076 ;{ }^{\star} p=0.0156\right)$ but, strikingly, not of PN-1 ${ }^{-1-}$ mice $(0.125 \pm 0.109 ; p=0.1875)(\mathrm{cm})$ (Fig. $6 \mathrm{H}$ ), indicating that the latter depend on whisker input less than wild-type mice. No obvious difference in approaching the task was observed, and these changes in performance did not appear to result from differences in general activity because, in an open-field test, $\mathrm{PN}-1^{-1-}$ mice showed comparable levels of activity as their wild-type littermates (Fig. 6I). They were also not resulting from differences in balance, speed, or coordination of movement, as a beam-balance test, in which a mouse learns to cross a narrow raised beam to reach a platform, showed no difference between $\mathrm{PN}-1^{-1-}$ mice and the wild-type littermates (data not shown). Together, these behavioral tests demonstrate that the absence of $\mathrm{PN}-1$ is accompanied by impairment of the whisker-to-barrel sensory system.

\section{Discussion}

Extracellular serine proteases play important roles in the adult nervous system. However, very little is known about their in vivo substrates and the contribution of their inhibitors. In this study, we have demonstrated the importance of the control of extracellular proteolysis for brain homeostasis through the activitydependent expression of $\mathrm{PN}-1$ and have shown that $\mathrm{PN}-1$ is essential for proper functioning of NMDA receptors and a sensory pathway.

The upregulation of PN-1 by neuronal activity extends and complements the previously demonstrated activity-dependent regulation of serine proteases (Seeds et al., 1995; Pawlak et al., 2003). In vitro, proteolysis can modify receptor signaling (Zhuo et al., 2000; Nicole et al., 2001), axonal outgrowth, and synaptic connectivity (Baranes et al., 1998); thus, its control during synaptic remodeling may be crucial for the fine tuning of plastic changes and limiting excessive proteolysis of target molecules. We provide, for the first time, strong in vivo evidence that extracellular proteolysis has to be tightly controlled during both normal brain function and activitydependent processes, otherwise, it would lead to NMDA receptor deficiency. The crucial role of PN-1 in this regard is demonstrated by the proteolytic imbalance in $\mathrm{PN}-1^{-1-}$ mice and the disrupted electrophysiological and functional performance of the whisker-to-barrel-cortex sensory pathway. The barrel cortex is a dynamic structure in which experience induces dramatic structural (Knott et al., 2002) and functional changes (Polley et al., 1999, 2004) as well as neuronal plasticity and LTD-like events (for review, see Fox, 2002). It is indicative that after singlewhisker experience, PN-1 is first upregulated in layer II/III cells. These cortical layers are involved in plastic events during changed sensory experience (Glazewski et al., 1998; Barth et al., 2000), and previous experiments have shown that after single-whisker experience first a subgroup of neurons in these layers, but not in layer IV, undergoes potentiation (Barth et al., 2000). The spreading of $\mathrm{PN}-1$ upregulation by $72 \mathrm{hr}$ of single-whisker experience possibly reflects the spreading of potentiation through the barrel cortex (Armstrong-James et al., 1992). Therefore, the pattern of activitydependent expression of PN-1 in these layers suggests a correlation with neuronal potentiation and remodeling.

Decreased SEP in $\mathrm{PN}-1^{-1-}$ mice and NMDA receptordependent EPSCs, paralleled by the functional impairment of the whiskers, show that $\mathrm{PN}-1$ is necessary for the proper function of this sensory pathway through the control of NMDA receptors. We cannot exclude that some other proteolysis-induced modifi- 
cations may contribute to these changes. However, our results show that NMDA receptors in the barrel cortex are strongly affected and that they are essential for normal SEP generation. Such a central role for NMDA receptors is supported by previously published data showing their significant contribution to barrel cortex sensory responses (Armstrong-James et al., 1993) and their importance for experience-dependent plasticity in the barrel cortex (Rema et al., 1998). The impairment in whiskerdependent sensory motor function in $\mathrm{PN}-1^{-1-}$ mice is particularly interesting in view of previous studies, showing that the barrel cortex is crucial for whisker-dependant performance (Hutson and Masterton, 1986; Guic-Robles et al., 1992; Troncoso et al., 2004). It is interesting to note that in $\mathrm{PN}-1^{-/-}$mice, the overall barrel cortex structure appeared normal, suggesting that changes in NMDA receptor function may be sufficient to induce such a sensory deficiency. However, we cannot exclude that some more subtle and still undetected developmental modifications in barrel cortex cytoarchitecture and connectivity could contribute to this phenomenon.

The results presented here suggest that enhanced proteolysis decreases the availability of functional NMDA receptors, leading to a partial loss of their function in some brain structures. This loss could be caused by tPA-dependant cleavage of NR1, which was demonstrated previously in vitro (Nicole et al., 2001). That such a cleavage could be taking place in $\mathrm{PN}-1^{-1-}$ mice is supported by the increased interaction between TPA and NR1 that we found. The fact that we have, so far, not detected cleaved forms of NR1 in synaptosomal fractions could result from their rapid turnover in vivo. Because the number of NMDA receptors can be dynamically regulated through constitutive and agonist-induced endocytosis (Roche et al., 2001; Nong et al., 2003; Nong et al., 2004 ), it is possible that in vivo proteolysis of NR1 leads to NMDA receptor destabilization and internalization. In vitro studies on the effects of chronic tPA exposure on NMDA receptor stability and signaling could help clarify this issue.

Another attractive mechanism explaining the NMDA receptor alterations in $\mathrm{PN}-1^{-1-}$ mice is suggested by a study showing modifications of NMDA receptor levels and signaling through the activation of LRP receptors (Qiu et al., 2002). Chronic exposure of hippocampal neurons to activated $\alpha_{2}$-macroglobulin, an LRP ligand, leads to a reduction in NR1 levels and decreased NMDA-dependent calcium responses. The mechanisms connecting LRP to the NMDA receptors remain unknown. However, in vitro experiments demonstrated binding of several cytoplasmic proteins to LRP, including the scaffold protein postsynaptic density-95 (PSD-95) (Gotthardt et al., 2000), which also associates with NMDA receptors (Kornau et al., 1995). In this respect, it is particularly interesting that PSD-95 has been implicated in the regulation of NMDA receptor endocytosis (Roche et al., 2001; Lavezzari et al., 2003). Therefore, increased tPA activity in PN$1^{-/-}$mice could induce an LRP-mediated internalization of NMDA receptors, affecting a variety of downstream signaling cascades, and thereby providing a mechanism for altering synaptic plasticity.

Our findings justify speculations about the potential roles for proteolysis-induced changes in NMDA receptor signaling in the intact brain. The possibility that such modifications occur in vivo has been, until now, postulated primarily for pathological states (Nicole et al., 2001). However, in normal brain functions, proteolysis could promote NMDA receptor endocytosis, thus providing a mechanism for a dynamic regulation of their number on the synapse. Obviously, proteolysis could also affect their function. The activity-evoked decrease of NR1 in $\mathrm{PN}-1^{-1-}$ mice opens the intriguing possibility that under physiological conditions, a local upregulation of proteolytic activity may induce modifications in NMDA receptor signaling, thus representing a novel mechanism of its regulation.

In summary, our study presents the first example of extracellular proteases downregulating a cell-surface neurotransmitter receptor in vivo and shows that $\mathrm{PN}$-1-mediated control of this phenomenon is essential for the proper functioning of a sensory pathway. NMDA receptors have critical roles in plasticity, cognition, synaptic transmission, and excitotoxicity in the CNS (CullCandy et al., 2001). Therefore, the deficiency described here is of central importance. Inappropriate NMDA receptor signaling has been implicated in disorders such as schizophrenia (Mohn et al., 1999), impaired object recognition, and associative memories (Nakazawa et al., 2002). Furthermore, the critical involvement of tPA in anxiety-like behavior (Pawlak et al., 2003) and spatial memory (Madani et al., 1999) may well be mediated through changes in NMDA receptor function. Consequently, we provide a model not only for in vivo molecular changes triggered by neuronal activity-dependent proteolytic events but also for studying other normal or pathological brain functions in which such modifications could play a role.

\section{References}

Armstrong-James M, Fox K, Das-Gupta A (1992) Flow of excitation within rat barrel cortex on striking a single vibrissa. J Neurophysiol 68:1345-1358.

Armstrong-James M, Welker E, Callahan CA (1993) The contribution of NMDA and non-NMDA receptors to fast and slow transmission of sensory information in the rat SI barrel cortex. J Neurosci 13:2149-2160.

Arnold PB, Li CX, Waters RS (2001) Thalamocortical arbors extend beyond single cortical barrels: an in vivo intracellular tracing study in rat. Exp Brain Res 136:152-168.

Bacskai BJ, Xia MQ, Strickland DK, Rebeck GW, Hyman BT (2000) The endocytic receptor protein LRP also mediates neuronal calcium signaling via N-methyl-D-aspartate receptors. Proc Natl Acad Sci USA 97: 11551-11556.

Baranes D, Lederfein D, Huang YY, Chen M, Bailey CH, Kandel ER (1998) Tissue plasminogen activator contributes to the late phase of LTP and to synaptic growth in the hippocampal mossy fiber pathway. Neuron 21:813-825.

Barneoud P, Gyger M, Andres F, Van der Loos H (1991) Vibrissa-related behavior in mice: transient effect of ablation of the barrel cortex. Behav Brain Res 44:87-99.

Barth AL, McKenna M, Glazewski S, Hill P, Impey S, Storm D, Fox K (2000) Upregulation of cAMP response element-mediated gene expression during experience-dependent plasticity in adult neocortex. J Neurosci 20:4206-4216.

Bisler S, Schleicher A, Gass P, Stehle JH, Zilles K, Staiger JF (2002) Expression of c-Fos, ICER, Krox-24 and JunB in the whisker-to-barrel pathway of rats: time course of induction upon whisker stimulation by tactile exploration of an enriched environment. J Chem Neuroanat 23:187-198.

Bu G, Williams S, Strickland DK, Schwartz AL (1992) Low density lipoprotein receptor-related protein/alpha 2-macroglobulin receptor is an hepatic receptor for tissue-type plasminogen activator. Proc Natl Acad Sci USA 89:7427-7431.

Buonomano DV, Merzenich MM (1998) Cortical plasticity: from synapses to maps. Annu Rev Neurosci 21:149-186.

Calabresi P, Napolitano M, Centonze D, Marfia GA, Gubellini P, Teule MA, Berretta N, Bernardi G, Frati L, Tolu M, Gulino A (2000) Tissue plasminogen activator controls multiple forms of synaptic plasticity and memory. Eur J Neurosci 12:1002-1012.

Cull-Candy S, Brickley S, Farrant M (2001) NMDA receptor subunits: diversity, development and disease. Curr Opin Neurobiol 11:327-335.

Dingledine R, Borges K, Bowie D, Traynelis SF (1999) The glutamate receptor ion channels. Pharmacol Rev 51:7-61.

Farrell DH, Wagner SL, Yuan RH, Cunningham DD (1988) Localization of protease nexin-1 on the fibroblast extracellular matrix. J Cell Physiol 134:179-188. 
Fox K (2002) Anatomical pathways and molecular mechanisms for plasticity in the barrel cortex. Neuroscience 111:799-814.

Glazewski S, Herman C, McKenna M, Chapman PF, Fox K (1998) Longterm potentiation in vivo in layers II/III of rat barrel cortex. Neuropharmacology 37:581-592.

Gloor S, Odink K, Guenther J, Nick H, Monard D (1986) A glia-derived neurite promoting factor with protease inhibitory activity belongs to the protease nexins. Cell 47:687-693.

Gotthardt M, Trommsdorff M, Nevitt MF, Shelton J, Richardson JA, Stockinger W, Nimpf J, Herz J (2000) Interactions of the low density lipoprotein receptor gene family with cytosolic adaptor and scaffold proteins suggest diverse biological functions in cellular communication and signal transduction. J Biol Chem 275:25616-25624.

Gualandris A, Jones TE, Strickland S, Tsirka SE (1996) Membrane depolarization induces calcium-dependent secretion of tissue plasminogen activator. J Neurosci 16:2220-2225.

Guic-Robles E, Jenkins WM, Bravo H (1992) Vibrissal roughness discrimination is barrel cortex-dependent. Behav Brain Res 48:145-152.

Hengst U, Albrecht H, Hess D, Monard D (2001) The phosphatidylethanolamine-binding protein is the prototype of a novel family of serine protease inhibitors. J Biol Chem 276:535-540.

Herz J, Strickland DK (2001) LRP: a multifunctional scavenger and signaling receptor. J Clin Invest 108:779-784.

Hutson KA, Masterton RB (1986) The sensory contribution of a single vibrissa's cortical barrel. J Neurophysiol 56:1196-1223.

Jenkinson EW, Glickstein M (2000) Whiskers, barrels, and cortical efferent pathways in gap crossing by rats. J Neurophysiol 84:1781-1789.

Knott GW, Quairiaux C, Genoud C, Welker E (2002) Formation of dendritic spines with GABAergic synapses induced by whisker stimulation in adult mice. Neuron 34:265-273.

Kornau HC, Schenker LT, Kennedy MB, Seeburg PH (1995) Domain interaction between NMDA receptor subunits and the postsynaptic density protein PSD-95. Science 269:1737-1740.

Lantz MS, Ciborowski P (1994) Zymographic techniques for detection and characterization of microbial proteases. Methods Enzymol 235:563-594.

Lavezzari G, McCallum J, Lee R, Roche KW (2003) Differential binding of the AP-2 adaptor complex and PSD-95 to the C-terminus of the NMDA receptor subunit NR2B regulates surface expression. Neuropharmacology 45:729-737.

Luthi A, Putten H, Botteri FM, Mansuy IM, Meins M, Frey U, Sansig G, Portet C, Schmutz M, Schroder M, Nitsch C, Laurent JP, Monard D (1997) Endogenous serine protease inhibitor modulates epileptic activity and hippocampal long-term potentiation. J Neurosci 17:4688-4699.

Madani R, Hulo S, Toni N, Madani H, Steimer T, Muller D, Vassalli JD (1999) Enhanced hippocampal long-term potentiation and learning by increased neuronal expression of tissue-type plasminogen activator in transgenic mice. EMBO J 18:3007-3012.

Mansuy IM, van der PH, Schmid P, Meins M, Botteri FM, Monard D (1993) Variable and multiple expression of Protease Nexin-1 during mouse organogenesis and nervous system development. Development 119:1119-1134.

Meier R, Spreyer P, Ortmann R, Harel A, Monard D (1989) Induction of glia-derived nexin after lesion of a peripheral nerve. Nature 342:548-550.

Meins M, Piosik P, Schaeren-Wiemers N, Franzoni S, Troncoso E, Kiss JZ, Brosamle C, Schwab ME, Molnar Z, Monard D (2001) Progressive neuronal and motor dysfunction in mice overexpressing the serine protease inhibitor protease nexin-1 in postmitotic neurons. J Neurosci 21:8830-8841.

Mohn AR, Gainetdinov RR, Caron MG, Koller BH (1999) Mice with reduced NMDA receptor expression display behaviors related to schizophrenia. Cell 98:427-436.

Nakazawa K, Quirk MC, Chitwood RA, Watanabe M, Yeckel MF, Sun LD, Kato A, Carr CA, Johnston D, Wilson MA, Tonegawa S (2002) Require- ment for hippocampal CA3 NMDA receptors in associative memory recall. Science 297:211-218.

Nicole O, Docagne F, Ali C, Margaill I, Carmeliet P, MacKenzie ET, Vivien D, Buisson A (2001) The proteolytic activity of tissue-plasminogen activator enhances NMDA receptor-mediated signaling. Nat Med 7:59-64.

Nong Y, Huang YQ, Ju W, Kalia LV, Ahmadian G, Wang YT, Salter MW (2003) Glycine binding primes NMDA receptor internalization. Nature 422:302-307.

Nong Y, Huang YQ, Salter MW (2004) NMDA receptors are movin' in. Curr Opin Neurobiol 14:353-361.

Pawlak R, Magarinos AM, Melchor J, McEwen B, Strickland S (2003) Tissue plasminogen activator in the amygdala is critical for stress- induced anxiety-like behavior. Nat Neurosci 6:168-174.

Petersen CC, Sakmann B (2000) The excitatory neuronal network of rat layer 4 barrel cortex. J Neurosci 20:7579-7586.

Polley DB, Chen-Bee CH, Frostig RD (1999) Two directions of plasticity in the sensory-deprived adult cortex. Neuron 24:623-637.

Polley DB, Kvasnak E, Frostig RD (2004) Naturalistic experience transforms sensory maps in the adult cortex of caged animals. Nature 429:67-71.

Qian Z, Gilbert ME, Colicos MA, Kandel ER, Kuhl D (1993) Tissueplasminogen activator is induced as an immediate-early gene during seizure, kindling and long-term potentiation. Nature 361:453-457.

Qiu Z, Strickland DK, Hyman BT, Rebeck GW (2002) $\alpha 2$-Macroglobulin exposure reduces calcium responses to $N$-methyl-D-aspartate via low density lipoprotein receptor-related protein in cultured hippocampal neurons. J Biol Chem 277:14458-14466.

Rema V, Armstrong-James M, Ebner FF (1998) Experience-dependent plasticity of adult rat $\mathrm{S} 1$ cortex requires local NMDA receptor activation. J Neurosci 18:10196-10206.

Roche KW, Standley S, McCallum J, Dune LC, Ehlers MD, Wenthold RJ (2001) Molecular determinants of NMDA receptor internalization. Nat Neurosci 4:794-802.

Sappino AP, Madani R, Huarte J, Belin D, Kiss JZ, Wohlwend A, Vassalli JD (1993) Extracellular proteolysis in the adult murine brain. J Clin Invest 92:679-685.

Scott RW, Bergman BL, Bajpai A, Hersh RT, Rodriguez H, Jones BN, Barreda C, Watts S, Baker JB (1985) Protease nexin. Properties and a modified purification procedure. J Biol Chem 260:7029-7034.

Seeds NW, Williams BL, Bickford PC (1995) Tissue plasminogen activator induction in Purkinje neurons after cerebellar motor learning. Science 270:1992-1994.

Seeds NW, Basham ME, Ferguson JE (2003) Absence of tissue plasminogen activator gene or activity impairs mouse cerebellar motor learning. J Neurosci 23:7368-7375.

Staiger JF, Bisler S, Schleicher A, Gass P, Stehle JH, Zilles K (2000) Exploration of a novel environment leads to the expression of inducible transcription factors in barrel-related columns. Neuroscience 99:7-16.

Troncoso E, Muller D, Czellar S, Zoltan KJ (2000) Epicranial sensory evoked potential recordings for repeated assessment of cortical functions in mice. J Neurosci Methods 97:51-58.

Troncoso E, Muller D, Korodi K, Steimer T, Welker E, Kiss JZ (2004) Recovery of evoked potentials, metabolic activity and behavior in a mouse model of somatosensory cortex lesion: role of the neural cell adhesion molecule (NCAM). Cereb Cortex 14:332-341.

van Praag H, Kempermann G, Gage FH (2000) Neural consequences of environmental enrichment. Nat Rev Neurosci 1:191-198.

Woolsey TA, Van der Loos H (1970) The structural organization of layer IV in the somatosensory region (SI) of mouse cerebral cortex. The description of a cortical field composed of discrete cytoarchitectonic units. Brain Res 17:205-242.

Zhuo M, Holtzman DM, Li Y, Osaka H, DeMaro J, Jacquin M, Bu G (2000) Role of tissue plasminogen activator receptor LRP in hippocampal longterm potentiation. J Neurosci 20:542-549. 